\title{
Assessment of Individual Radiosensitivity in Inhabitants of Takandeang Village - A High Background Radiation Area in Indonesia
}

\author{
D. Ramadhani ${ }^{1,2 *}$ S. Purnami ${ }^{1}$, S. Nurhayati ${ }^{1}$, M. Lubis ${ }^{1}$, D. Teriana ${ }^{1}$, W. Mailana ${ }^{1}$, \\ K.D. Purwanti ${ }^{1}$, E. Pudjadi ${ }^{1}$, I. Kashiwakura ${ }^{3}$, R. Okazaki ${ }^{4}$ and M. Syaifudin ${ }^{1}$ \\ ${ }^{I}$ Center for Radiation Safety Technology and Metrology, National Nuclear Energy Agency, \\ Jl. Lebak Bulus Raya No. 49, Jakarta 12070, Indonesia \\ ${ }^{2}$ Doctoral Program for Biomedical Sciences, Faculty of Medicine, Universitas Indonesia \\ Jl. Salemba Raya No. 6, Ged. IMERI, Tower b, Lt. 11, Jakarta Pusat 10430, Indonesia \\ ${ }^{3}$ Department of Radiological Life Sciences, Hirosaki University Graduate School of Health Sciences, \\ 66-1 Hon-cho, Hirosaki 036-8564, Japan \\ ${ }^{4}$ Department of Radiological Health Science, Institute of Industrial Ecological Sciences, \\ University of Occupational and Environmental Health, Japan, \\ 1-1 Iseigaoka Yahatanishi-ku, Kitakyushu 807-8555. Japan
}

\section{ARTICLE INFO}

Article history:

Received 13 October 2017

Received in revised form 18 December 2018

Accepted 18 December 2018

\section{Keywords:}

G2 MN assay

High background radiation area

Mamuju

Radiosensitivity

Polymorphism

\begin{abstract}
A B S T R A C T
People living in high background radiation areas (HBRAs) possibly develop the radioadaptive response (RAR) phenomenon. The Mamuju area in West Sulawesi Indonesia is known as an HBRA in Indonesia due to its high natural uranium contents. It is possible that RAR has developed in Mamuju inhabitants. To prove this hypothesis, here in this study, evaluation of the individual radiosensitivity in the inhabitants of Takandeang Village, Mamuju, was conducted using $\mathrm{G}_{2}$ micronucleus (MN) assay. Association between blood groups and TP53 Arg72Pro polymorphism with individual radiosensitivity was also evaluated in this study. Using $\mathrm{G}_{2} \mathrm{MN}$ assay, we assessed the individual radiosensitivity of Takandeang Village inhabitants and control samples. For each sample, three parameters were calculated. The spontaneous (baseline) $\mathrm{MN}$ number, $\mathrm{MN}$ number after 0.5 Gy in vitro irradiation, and radiation-induced $\mathrm{MN}$ were calculated to predict the individual radiosensitivity. The radiation-induced $\mathrm{MN}$ was defined by subtracting the spontaneous MN number from the MN number after irradiation. The mean and SD of the number of micronuclei induced by radiation found in control group (CG) was set as the cutoff value to determine the individual radiosensitivity in all samples. The occurrence of a radiation-induced $\mathrm{MN}$ value higher than the mean CG + 1SD CG was scored as 1, indicating a milder radiosensitive phenotype, whereas a result higher than the mean $\mathrm{CG}+2 \mathrm{SD}$ CG was scored as 2 , and indicated a more severe radiosensitive phenotype. When the individual value was lower than the mean CG + 1SD CG, a score of 0 was attributed to the tested subject. The results showed that four individuals in Takandeang Village inhabitants had a milder radiosensitive phenotype, while the others were categorized as normal radiosensitive. A similar finding was also found in control samples. Our study failed to find any correlation between radiosensitivity and either blood group or the TP53 Arg72Pro polymorphism. Overall, our study revealed the possibility of RAR phenomena in Takandeang Village inhabitants. Further investigation using a different point of radiation dose value and larger sample number should be performed to validate this study results.
\end{abstract}

(C) 2019 Atom Indonesia. All rights reserved

higher than the worldwide average background dose for a human being $(2.4 \mathrm{mSv} / \mathrm{y})$ [1]. Several areas such as Ramsar in Iran and Kerala (India) are considered as HBRAs because the level of natural background radiation in these areas can reach 10 - 100 times the worldwide average background dose [2,3]. The Mamuju area in West Sulawesi,

\footnotetext{
${ }^{*}$ Corresponding author.

E-mail address: dhani02@batan.go.id

DOI: https://doi.org/10.17146/aij.2019.724
} 
Indonesia, is also known for its high radiation dose rates due to the Naturally Occurring Radioactive Material (NORM), especially the natural uranium contents. The average uranium concentration in Mamuju is $25 \mathrm{ppm}$ eU, while the average abundance in the Earth's crust is about 3 ppm eU. Six areas in Mamuju are considered as anomaly areas because they have background radiation dose rates of more than $400 \mathrm{nSv} / \mathrm{h}$. These areas are Ahu, Takandeang, Botteng, Pengasaan, Tande-Tande, and Mamunyu. Three areas (Tande-Tande, Takandeang, and Botteng) are used for settlement, while Ahu, Pengasaan, and Mamunyu only consist of forest and weeds [4].

Our previous study that evaluated the expression of $\gamma-\mathrm{H} 2 \mathrm{AX}$ foci, micronucleus, and comet tail as markers of deoxyribonucleic acid (DNA) damage revealed that the means of $\gamma$-H2AX foci, micronucleus, and comet tail length in Mamuju were not significantly higher compared to control samples $[3,5,6]$. This study result leads to the possibility of radioadaptive response (RAR) in Mamuju inhabitants. However, our previous studies failed to find that RAR phenomena was developing in the inhabitants of Botteng Village, Mamuju [7]. Here in this study, to validate that RAR developed among Mamuju inhabitants, we assessed the individual radiosensitivity of Takandeang Village inhabitants using the chromosomal aberration assay. Until now the chromosomal aberration assay is the most commonly used assay to predict individual radiosensitivity. In brief, lymphocytes are irradiated in vitro in the $G_{0}$ phase and then stimulated to proceed in the cell cycle [8]. Another technique also commonly used for the assessment of individual radiosensitivity is $\mathrm{G}_{2}$ micronucleus (MN) assay. This assay was initially developed by Claes et al. in 2013 [9]. They optimized this assay to detect defects in the $S$ or $G_{2}$ phase of the cell cycle. This assay also efficiently detected increased radiosensitivity in the ataxiatelangiectasia (A-T) patient.

Nowadays it is well known that radiosensitivity can be influenced by genetic factors in individuals $[10,11]$. Among many genes involved in radiosensitivity regulation, the TP53 has been explored as a potential target for radiosensitization and radioprotection. The TP53 gene is located on the chromosome $17 \mathrm{p} 13$ and consists of 11 exons $[12,13]$. The transcription factor TP53 is known as a key molecule for determining cellular responses to ionizing radiation by initiating a spectrum of celltype specific responses, including cell cycle arrest, senescence, apoptosis, and DNA damage repair $[12,14,15]$. Genetic polymorphisms in TP53 gene can affect some of TP53 functions. The mostinvestigated polymorphism of TP53 gene is
Arg72Pro in codon 72 of exon 4 as the proline-rich region $(\mathrm{G}>\mathrm{C}$, rs1042522) [16]. This polymorphism encodes substitution from arginine to proline in the TP53 protein. The TP53 72Pro has been reported to be a more efficient activator of DNA-repair and cell cycle arrest than TP53 72Arg [17]. Thus, individuals exhibiting TP53 72Arg will be more sensitive to ionizing radiation. In contrast, Brasil-Costa et al. stated that individuals with homozygous proline coding alleles $(\mathrm{C} / \mathrm{C})$ genotype in codon 72 of exon 4 in TP53 gene are more radiosensitive and should be subjects for public health action in regions with environmental radioisotopes [18]. To validate this contradictory finding, here in this study we evaluated the correlation between TP53 Arg72Pro polymorphism and individual radiosensitivity using $\mathrm{G}_{2} \mathrm{MN}$ assay. It is also well known that inherent characteristics are one of the important reasons for differences in radiation sensitivity. The blood group is an inherent characteristic and the classification is based on the presence or absence of $\mathrm{ABO}$ blood group antigens on the surface of red blood cells. Thus, in this study we also evaluated the association between blood group and individual radiosensitivity to elucidate the roles of blood group in determining the individual radiosensitivity.

\section{EXPERIMENTAL METHODS}

\section{Indoor and outdoor gamma dose rate measurement}

The indoor and outdoor background gamma radiation measurements were performed using a gamma spectrometer (Exploranium GR-135 Plus) calibrated in the secondary standard dosimetry laboratory under the National Nuclear Energy Agency of Indonesia. In the outdoor gamma dose rate measurements, the detector was placed at least $6 \mathrm{~m}$ away from the walls of any nearby building and $1 \mathrm{~m}$ above ground level. For the indoor measurements inside the houses, the detector was placed $1 \mathrm{~m}$ above ground level with a total exposure time of 10 minutes. The average of all measurements in ten houses was calculated and considered as the outdoor and indoor gamma dose rates of Takandeang Sub-village in Takandeang Village. Takandeang Village consists of nine subvillages, namely Salumatti, Taloba, Limbeng, Salubiru, Takandeang, Palada, Rantedunia, Tabanga-banga, and Bettengkata. The Takandeang Sub-village was chosen in this study as the representative of Takandeang Village inhabitants. Takandeang Village is part of Tapalang Sub-district in Mamuju Regency. The control area in Topoyo Sub-district is part of Mamuju Tengah Regency. Both Mamuju and Mamuju Tengah regencies are 
parts of Mamuju District. Mamuju District is located between $1^{\circ} 38^{\prime} 110^{\prime \prime}$ - $2^{\circ} 54^{\prime} 552^{\prime \prime}$ South and $11^{\circ} 54^{\prime} 47^{\prime}$ ' - $13^{\circ} 5^{\prime} 35^{\prime}$ ' East with an area of $5056.19 \mathrm{~km}^{2}$ [19].

\section{Annual effective dose calculation}

The annual effective dose from indoor and outdoor background gamma dose rate was estimated by following eq. (1) [20].

$$
E=\left(D_{\text {out }} \times O F_{\text {out }}+D_{\text {in }} \times O F_{\text {in }}\right) \times T \times C C
$$

Here $E(\mathrm{mSv} / \mathrm{y})$ is the annual effective dose, $D_{\text {out }}$ and $D_{\text {in }}(\mathrm{nSv} / \mathrm{h})$ are average per-hour outdoor and indoor gamma dose rates, $T$ is the number of hours in a year $(8760 \mathrm{~h} / \mathrm{y}), O F_{\text {out }}$ and $O F_{\text {in }}$ are outdoor and indoor occupancy factors $(30 \%$ and $70 \%$ for outdoor and indoor, respectively), and $C C$ is the conversion coefficient ( 0.7 for adults) reported by UNSCEAR to convert absorbed dose in air to the effective dose in human [21]. The occupancy factor for indoor and outdoor was calculated based on the observation of Takandeang Sub-village inhabitants that spent almost 8 hours outdoor and 16 hours indoor per day.

\section{Blood sampling}

Twenty healthy adult subjects from Takandeang Sub-village and twenty healthy adult subjects from normal background radiation areas (NBRAs) were included in this study. Peripheral blood samples were collected by venipuncture using heparinized vacutainer tubes. Two vacutainer tubes were obtained from each sample. The study was approved by Ethics Committee of the National Institute of Health Study and Development, Indonesian Ministry of Health, with the decree number LB.02.01/5.2.KE.051/2015 date of January 29, 2015. All procedures performed in this study were in accordance with the ethical standards of the national research committee and with the 1964 Helsinki declaration and its later amendments or comparable ethical standards. Informed consent was obtained from every donor. The inclusion criteria used in this study were having complete information on gender and age, absence of intake of alcohol, no family history of genetic disorder, and no exposure to ionizing radiation except for natural background radiation. The exclusion criteria was having a medical treatment especially radiation exposure. The ABO blood typing was performed using monoclonal grouping kit (Fortress Diagnostics Ltd, UK)

\section{$\mathrm{G}_{2} \mathrm{MN}$ assay}

$\mathrm{G}_{2}$ MN assay was conducted based on the Baert et al. [22] with modifications. Two cultures were set up in $15 \mathrm{~mL}$ centrifuge tube for each blood sample. Whole blood samples were cultured for 72 hours in an incubator at $37{ }^{\circ} \mathrm{C}$ containing $5 \% \mathrm{CO}_{2}$. The culture medium consisted of $4.5 \mathrm{~mL}$ of Rosewell Park Memorial Institute (RPMI) 1640 supplemented with $20 \%$ heat-inactivated fetal bovine serum (FBS), $1 \%$ streptomycin/penicillin, and $0.1 \mathrm{~mL}$ of phytohemagglutinin (PHA). At 44 hours post-PHA stimulation, one culture tube from each sample was irradiated in-vitro with 0.5 Gy $\gamma$ rays at a dose rate of $1 \mathrm{~Gy} / \mathrm{min}$, whereas the other tube was sham-irradiated. Irradiation process was performed at the Multi Purpose Panoramic Irradiator (IRPASENA) at the Center for Isotopes and Radiation Application (PAIR), National Nuclear Energy Agency of Indonesia (BATAN). The culture tubes were placed on polystyrene foam rack at a distance of $108 \mathrm{~cm}$ from the source of the panoramic irradiator. The irradiations process was carried out at room temperature.

Immediately after irradiation, cytochalasin-B at a final concentration of $6 \mu \mathrm{g} / \mathrm{ml}$ was added to the cultures tubes, including non-irradiated culture tubes. The cells were then centrifuged for 10 minutes at $1000 \mathrm{rpm}$ and re-suspended in $7 \mathrm{ml}$ of $0.075 \mathrm{M}$ cold $\left(4{ }^{\circ} \mathrm{C}\right) \mathrm{KCl}$. The cells were then centrifuged again for 8 minutes at $1000 \mathrm{rpm}$ and resuspended in freshly made fixative consisting of methanol:acetic acid (10:1) diluted 1:1 with Ringer's solution. The cells were then washed with two to three further changes of freshly-prepared fixative consisting of methanol:acetic acid (10:1) without Ringer's solution until the cell suspension is clear. The cell suspension was then stored at $-20{ }^{\circ} \mathrm{C}$ at least for one night until the slide preparation was conducted. Fixed cells were dropped onto clean, wet slides, dried and stained with $4 \%$ Giemsa solution $(\mathrm{pH}=6.8)$ for 12 minutes. Six slides were obtained from each sample comprised of four slides from the irradiated tube and two slides from the shamirradiated tube. For each sample, one reader scored one thousand binucleated lymphocytes from at least two slides at the magnification of $400 \times$. The slides were then analyzed based on an IAEA publication [23].

The individual radiosensitivity was calculated based on Baert et al. [24] with minor modifications. For each sample, three parameters were calculated. The spontaneous (baseline) MN number, MN number after 0.5 Gy in vitro irradiation, and radiation-induced $\mathrm{MN}$ were calculated to predict the individual radiosensitivity. The radiation-induced MN was defined by subtracting the spontaneous MN number from the $\mathrm{MN}$ number after irradiation. The mean and standard deviation (SD) of the 
number of micronucleus induced by radiation found in control group (CG) was set as the cutoff value to determine the individual radiosensitivity in all samples. The radiation-induced MN higher than the mean CG + 1SD CG was scored as 1 , indicating a milder radiosensitive phenotype, whereas a result higher than the mean CG + 2SD CG was scored as 2 , and indicated a more severe radiosensitive phenotype. When the individual value was lower than the mean $C G+1 S D C G$, a score of 0 was attributed to the tested subject.

\section{DNA extraction and genotyping}

Genomic DNA was extracted from peripheral blood using a DNA Isolation Kit (Roche) according to the manufacturer's protocol. The TP53 Arg72Pro (rs1042522) polymorphism genotyping was performed with a real-time polymerase chain reaction (RT-PCR), using a TaqMan (Applied Biosystems) single-nucleotide polymorphism (SNP) genotyping assay. The primer pairs used were purchased from Applied Biosystems for rs 1042522. Real-time PCR was performed using Roche LightCycler Nano in a $20 \mu \mathrm{L}$ reaction volume containing $2 \mu \mathrm{L}$ PCR primer, $10 \mu \mathrm{l}$ of Taqman GTXpress Mastermix for genotyping, $4 \mu \mathrm{l}$ of genomic DNA, and $4 \mu \mathrm{l}$ of PCR-grade water. The PCR conditions were as follows: a $10 \mathrm{~min}$ denaturation step at $95{ }^{\circ} \mathrm{C}$ followed by 45 cycles of $95{ }^{\circ} \mathrm{C}$ for 15 seconds $\mathrm{min}$ and a $60{ }^{\circ} \mathrm{C}$ for 60 seconds. Genotypes were determined using LightCycler Nano Software 1.0.

\section{Statistical analysis}

The $\chi^{2}$-test analysis was used to verify the statistical differences of the categorical variable (gender) in Takandeang Sub-village inhabitants and control samples. T-test analysis was used for the continuous variable, namely age, between Takandeang Sub-village inhabitants and control samples. The median, interquartile range, average and standard deviation of micronuclei yields (number of MN/1000 BN cells) in both shamirradiated and irradiated tubes were assessed in each group of subjects. T-test analysis also used to evaluate the significant difference of spontaneous $\mathrm{MN}$ number, MN number after 0.5 Gy in vitro irradiation, radiation-induced $\mathrm{MN}$ and distribution of TP53 Arg72Pro polymorphism between Takandeang Sub-village inhabitants and control groups. Hardy-Weinberg equilibrium was tested on genotypic data using SNPStats (http://bioinfo.iconcologia.net/SNPstats) [25]. The one-way ANOVA test was used to find out the different of $\mathrm{MN}$ frequencies in each genotype. The significance value was set at $p<0.05$. All tests were conducted using SPSS for Windows version 22.0.

\section{RESULTS AND DISCUSSION}

\section{Indoor and outdoor gamma dose rate}

The minimum and maximum gamma dose rates for indoor measurements were $320 \mathrm{nSv} / \mathrm{h}$ and $500 \mathrm{nSv} / \mathrm{h}$, while for outdoor measurements were $340 \mathrm{nSv} / \mathrm{h}$ and $560 \mathrm{nSv} / \mathrm{h}$. The average indoor and outdoor gamma dose rates were $398 \pm 17.68 \mathrm{nSv} / \mathrm{h}$ and $450 \pm 25.21 \mathrm{nSv} / \mathrm{h}$, respectively.

\section{Annual effective dose}

The average annual effective dose for Takandeang Sub-village was $2.52 \mathrm{mSv} / \mathrm{y}$, with the range spanning from 1.99 to $3.17 \mathrm{mSv} / \mathrm{y}$. These values are 2.2 to 3.6 times as high as the estimated world average values of effective environmental gamma dose rate due to the cosmic rays and terrestrial gamma radiation, as reported by UNSCEAR, that is $0.87 \mathrm{mSv} / \mathrm{y}$ [21].

\section{Individual radiosensitivity}

The $t$-test analysis revealed that the mean age of individuals from Takandeang Sub-village was not significantly different compared with control samples. The mean age of Takandeang Sub-village inhabitants used in this study was $42 \pm 3.46$ with a range of 17 to 77 years. The ages of controls ranged from 20 to 68 years with a mean of $39.25 \pm 3.29$, respectively. The $\chi^{2}$-test analysis also revealed that the gender compositions of Takandeang Sub-village inhabitants and control samples were not significantly different. The detail characteristics data of the samples are presented in Table 1.

Table 1. The detail characteristics data of the samples ( $n$ : number of samples).

\begin{tabular}{cccc}
\hline Group & $\begin{array}{c}\text { Takandeang Sub- } \\
\text { village Inhabitants, } \\
n(\%)\end{array}$ & $\begin{array}{c}\text { Control, } \\
n(\%)\end{array}$ & $p$-values \\
\hline Mean Age & $42 \pm 15.47$ & $39.25 \pm 14.74$ & 0.56 \\
Gender & $10(50)$ & $8(40)$ & 0.52 \\
Male & $10(50)$ & $12(60)$ & \\
Female & $20(100)$ & $20(100)$ & \\
Totals & & & \\
Blood Group & $4(20)$ & $7(35)$ & 0.47 \\
A & $2(10)$ & $3(15)$ & \\
B & $7(35)$ & $2(10)$ & \\
AB & $7(35)$ & $8(40)$ & \\
O & $20(100)$ & $20(100)$ & \\
Totals & &
\end{tabular}


The mean number of spontaneously occurring $\mathrm{MN}$ and $\mathrm{MN}$ numbers before and after exposure to 0.5 Gy in Takandeang Sub-village inhabitants and control samples are summarized in Table 2 . The mean spontaneous $\mathrm{MN}$ number ( 0 Gy) in Takandeang Sub-village inhabitants was significantly lower compared with the control group $(p=0.03)$ (Fig. 1). The non-significant difference was found when comparing $\mathrm{MN}$ number after 0.5 Gy exposure and radiation-induced $\mathrm{MN}$ between Botteng Village inhabitants and control samples $(p>0.05)$ (Fig. 2). In this study, the cutoff values to define the individual radiosensitivity are 52.65 and 70.46; they are derived from the mean value of the radiation-induced $\mathrm{MN}$ in control group which was $34.85 \pm 17.8$. Using these values, four individuals in the control group were categorized as having a milder radiosensitive phenotype, while the others were categorized as normal radiosensitive (Fig. 3). A similar result was found in Takandeang Subvillage inhabitants were four individuals were categorized as having a milder radiosensitive phenotype, while the others were categorized as normal radiosensitive (Fig. 4).

Table 2. The median, mean and SEM of the micronucleus per $1000 \mathrm{BNC}$.

\begin{tabular}{lccc}
\hline Group data & 0 Gy & 0.5 Gy & $\begin{array}{c}\text { Radiation- } \\
\text { induced } \\
\text { MN }\end{array}$ \\
\hline $\begin{array}{l}\text { Control Samples } \\
\text { Median }\end{array}$ & 23.00 & 57.50 & 33.50 \\
Mean & 21.30 & 56.15 & 34.85 \\
SEM & 2.402 & 3.368 & 3.982 \\
Takandeang Village & & & \\
$\quad$ Median & 13.50 & 55.50 & 39.00 \\
Mean & $14.80[S]$ & $52.70[N S]$ & $37.90[N S]$ \\
SEM & 1.702 & 3.926 & 3.667 \\
\hline
\end{tabular}

$S$ : significantly different from control according to $t$-test $(p<0.05)$ $N S$ : not significantly different from control according to $t$-test $(p>0.05)$

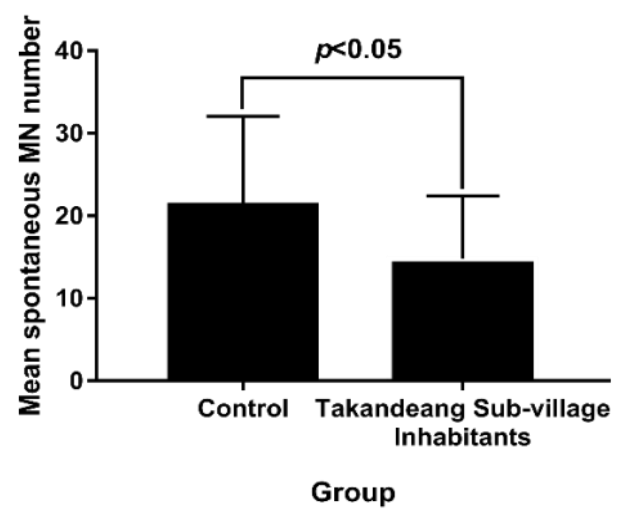

Fig. 1. Mean spontaneous MN number in control samples and Takandeang Sub-village inhabitants (significantly different from control according to $t$-test with $p<0.05$ ).

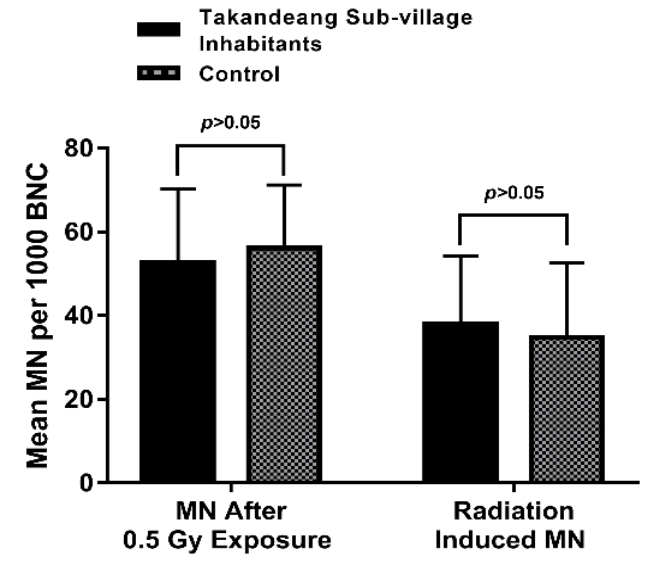

Fig. 2. Mean MN number after 0.5 Gy exposure and radiationinduced MN in control and Takandeang Sub-village inhabitants (not significantly different from control according to $t$-test with $p>0.05$ ).

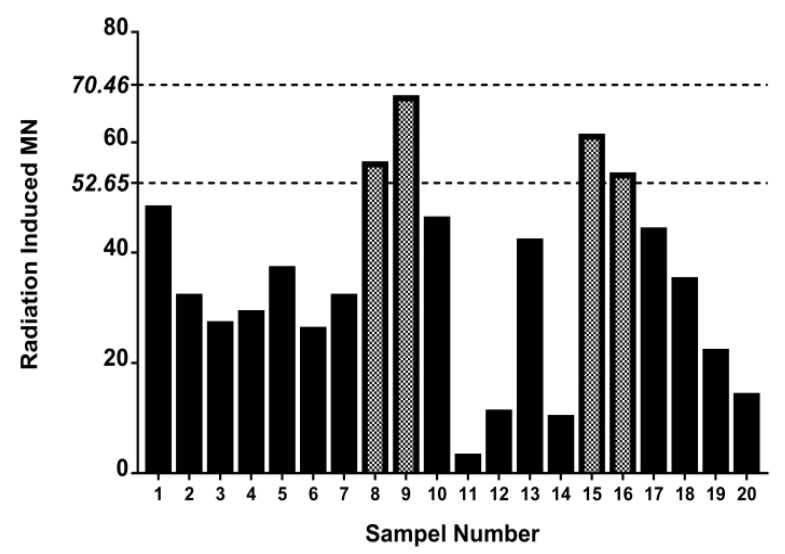

Fig. 3. Radiation-induced $\mathrm{MN}$ after 0.5 Gy exposure in control samples. Two lines indicated the cutoff values to defined the individual radiosensitivity which were 52.65 and 70.46. Pattern bars indicated the milder radiosensitive phenotype.

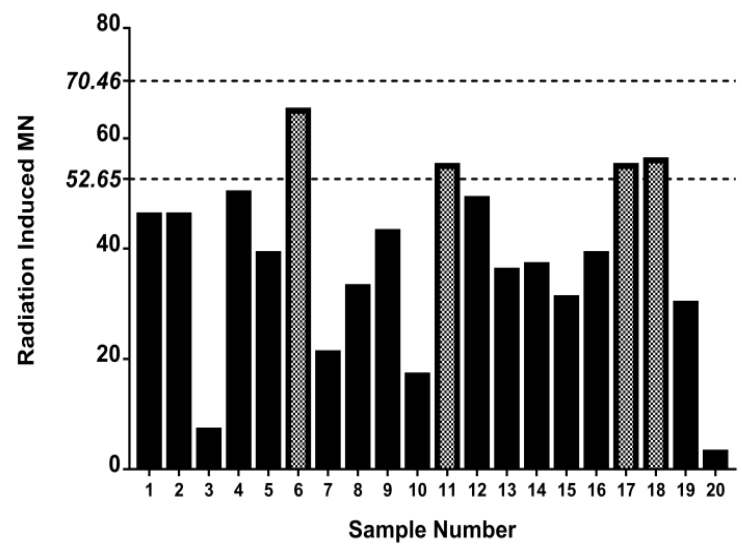

Fig. 4. Radiation-induced $\mathrm{MN}$ after 0.5 Gy exposure in Takandeang Sub-village inhabitants. Two lines indicated the cutoff values to define the individual radiosensitivity, namely 52.65 and 70.46. Pattern bars indicate the milder radiosensitive phenotype.

Based on this result and the mean of spontaneous MN number, our study showed the possibility of the RAR in Takandeang Sub-village 
inhabitants. The existence of radiosensitivity has been confirmed by molecular or cytogenetic assays throughout DNA repair and MN analysis [26]. A study by Mohammadi et al. in 2006 that evaluated the radiosensitivity in Ramsar inhabitants using the apoptosis, MN, and alkaline comet assays revealed the possibility of RAR in healthy individuals living in Ramsar, Iran [27]. In particular, the MN yield of Ramsar inhabitants that occurred after exposure to 4 Gy $\gamma$-rays was significantly lower compared to control group. Interestingly in this study, the spontaneous MN number in Takandeang Subvillage inhabitants was significantly lower compared to control group. The RAR in Takandeang Sub-village inhabitants probably is due to highly efficient DNA repair processes. Masoomi et al. in 2006 evaluated the DNA repair in Ramsar inhabitants by comet assay [28]. They found that Ramsar inhabitants who had received a lower chronic dose (ranged from 0.53 to $7.62 \mathrm{mSv} / \mathrm{y}$ ) showed a lower radiosensitivity and more DNA repair rate compared to control samples. The Takandeang Sub-village inhabitants were received $2.52 \mathrm{mSv} / \mathrm{y}$ from the terrestrial exposure without concerning the ingestion and inhalation exposures from radon gas. Thus, it is possible that the DNA repair in Takandeang Sub-village inhabitants was more efficient than in the control samples. Further investigation should be performed to validate this hypothesis. Concerning the effect of confounding factors, especially age, on the individual radiosensitivity, our study failed to find an association between age and radiosensitivity. This is because the ages of individuals categorized as having a milder radiosensitive phenotype were in the range of 39-73 years.

In this study, we used the $\mathrm{G}_{2} \mathrm{MN}$ assay to evaluate the radiosensitivity of people living in the high background radiation area. This assay has been used in several studies, specifically to investigate the radiosensitivity in cancer patients $[29,30]$. The radiation dose used in this study is $0.5 \mathrm{~Gy}$. This value is much lower than the value of 2 Gy that is commonly used in the $\mathrm{G}_{2}$ assay. The $0.5 \mathrm{~Gy}$ point dose was used in this study because the 2 Gy radiation dose gave low numbers of $\mathrm{BNC}$ in our preliminary study (data not shown). However, the use of another point dose, i.e., $1.5 \mathrm{~Gy}$, should be used in the further study to validate this study result.

\section{Association between blood group and radiosensitivity}

The means of radiation-induced $\mathrm{MN}$ in different blood groups are shown in Fig. 5. ANOVA test revealed that the difference in each blood type was not significant $(p>0.05)$. However, our study showed that the $\mathrm{O}$ blood type has the lowest value of the mean radiation-induced MN (Fig. 5). A study by Elahimanesh et al. in 2013 suggested that $\mathrm{A}+$ blood type was the most radiosensitive and $\mathrm{O}+$ have the lowest radiosensitivity [10]. Elahimanesh et al. stated that there is a possibility of an association between some alleles of ABO blood groups and specific alleles of genes involved in DNA double strand breaks repair. They also stated that molecular investigation to evaluate candidate loci involved in the DNA repair systems on chromosome 9 near $\mathrm{ABO}$ locus at 9q34 should be performed in order to validate the association between blood groups and radiosensitivity [10].

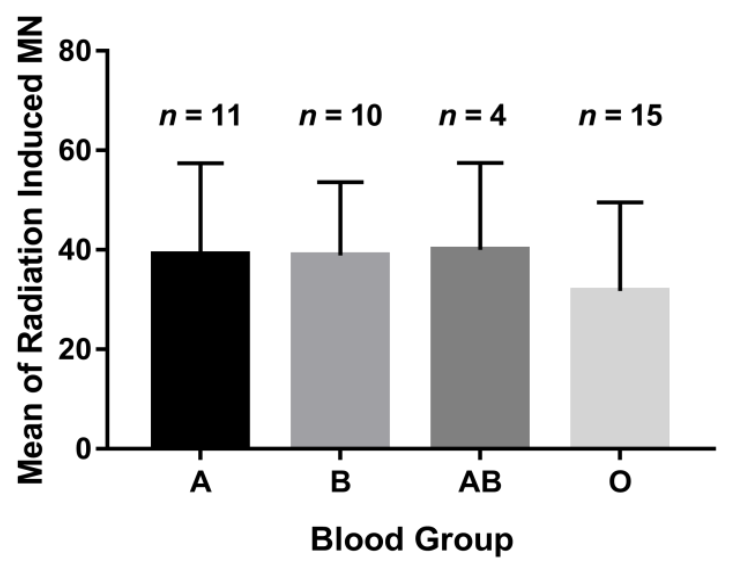

Fig. 5. Mean MN numbers of different blood groups in all samples ( $n$ : number of samples).

Regarding the $\mathrm{Rh}$ system, the study by Khosravifarsani et al. showed that Rh- was less sensitive to radiation compared to $\mathrm{Rh}+$ [31]. Since in our study all samples have $\mathrm{Rh}+$, we cannot evaluate the association between $\mathrm{Rh}$ and radiosensitivity. Another study by Khosravifarsani et al. in 2012 showed that radiosensitivity of lefthanders is higher compared to right-handers in healthy female samples [32]. Unfortunately, in this study, we did not evaluate whether the samples are left or right handers.

\section{Association between TP53 Arg72Pro polymorphism and radiosensitivity}

The genotype distribution in both of Takandeang Sub-village inhabitants and control samples followed the Hardy-Weinberg equilibrium $(H W E)$ (Table 3). The distribution of TP53 Arg72Pro in Takandeang Sub-village inhabitants was not statistically different compared with the control group $(p>0.05)$. 
Table 3. Distribution of p53 Arg72Pro in Takandeang Subvillage inhabitants and control samples.

\begin{tabular}{ccccc}
\hline Gene & Genotype & $\begin{array}{c}\text { Takandeang } \\
\text { Sub-village } \\
\text { inhabitants, } \\
\mathrm{n}(\%)\end{array}$ & $\begin{array}{c}\text { Controls, } \\
\mathrm{n}(\%)\end{array}$ & $\begin{array}{c}\text { Total, } \\
\mathrm{n}(\%)\end{array}$ \\
\hline \multirow{2}{*}{ TP53 } & $C C$ & $13(65)$ & $7(35)$ & $20(50)$ \\
& $C G$ & $5(25)$ & $12(60)$ & $17(42)$ \\
Allele & $G G$ & $2(10)$ & $1(5)$ & $3(8)$ \\
frequency & $G$ & $0.78[N S]$ & 0.65 & 0.71 \\
\hline
\end{tabular}

$N S$ : Not difference with control samples; $p>0.05$

One-way ANOVA test revealed that the means of radiation-induced $\mathrm{MN}$ for each genotype $(\mathrm{CC} / \mathrm{CG} / \mathrm{GG})$ in Takandeang Sub-village and control samples were not significantly different. A similar result was also found when all samples were pooled $(p>0.05)$ (Fig. 6). Here in this study, we evaluated the association between TP53 Arg72Pro polymorphism and radiosensitivity assessed using $\mathrm{G}_{2} \mathrm{MN}$ assay. The wild-type TP53 gene normally responds to radiation with a high level of expression and subsequently mediates cell cycle arrest and DNA repair activation [33]. Therefore, TP53 is important for monitoring radiosensitivity to both high and low doses of radiation, alone or in combination with other stressors [18].

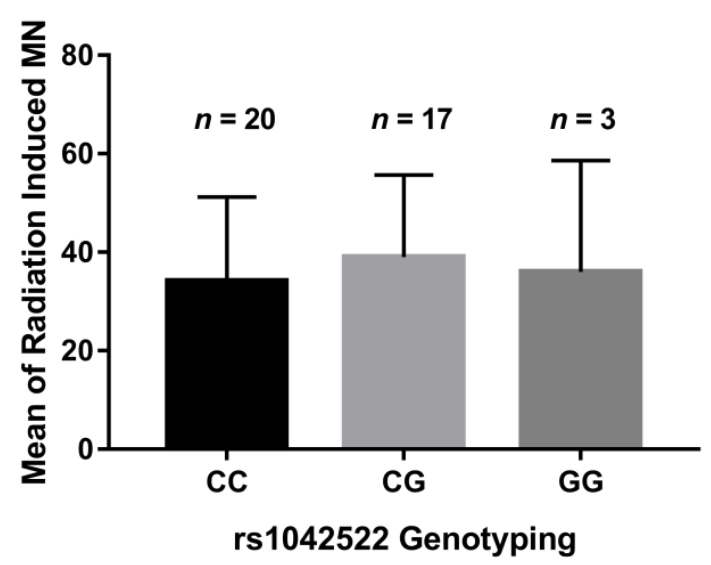

Fig. 6. The mean of radiation-induced $M N$ after 0.5 Gy exposure of each genotype in all samples ( $n$ : number of samples).

In this study, we failed to find an association between TP53 Arg72Pro polymorphism and radiosensitivity in people receiving the chronic low dose rate exposure. Until now, there have not been many studies on the correlation between Arg72Pro and radiosensitivity. Comprehensive studies about the association between TP53 Arg72Pro polymorphism and radiosensitivity were already performed by Alsbeih et al. [8,28]. In 2007 Alsbeih et al. observed an increase of survival in fibroblast cells using clonogenic assay after exposed to single radiation dose ranging from 0 to 4 Gy in cells containing Proline coding allele in TP53 (Arg72Pro) gene. They stated that amino acid substitution variant may affect the structure of the putative SH3binding domain and the Pro variant could have a suboptimal protein function culminating in less stringent control of the cell cycle and DNA repair that otherwise would eliminate the damaged cells from the cellular population and, therefore, lead to greater survival [34]. Another study by Alsbeih et al. in 2007 also revealed a similar result, namely that the variant TP53 Arg72 allele was associated with a decrease in radiosensitivity [35]. A study by Schwartz et al. in 2011 using the human lymphoblast cells revealed that cell lines with homozygous Proline coding allele were more likely to be resistant to radiation-induced chromatid break formation in $\mathrm{G}_{2}$ chromosomal radiosensitivity assay compared to those containing two arginine coding alleles [36]. Another study by Pereira et al. in 2011 revealed that the homozygous arginine coding alleles increase the number of cells with karyorrhexis in buccal cells of head and neck cancer patients after the first session of radiotherapy [37].

The effect of low dose and low dose rate of radiation is inconsistent and inconclusive [38]. However, it is well known that RAR could be induced by chronic low dose exposure, even though the molecular mechanism underlying RAR is not yet clearly understood. It is assumed that RAR may be either due to the enhanced repair of DNA damage or due to protection against the adverse effects induced by high challenging doses [39]. The high level of DNA damage in people living in HBRAs could come from the high level of reactive oxygen species (ROS). As already known, ionizing radiation can generate ROS, cause DNA damage, and induce delays in different phases of the cell cycle $[40,41]$. Thus, it can be assumed that the antioxidant level in HBRA inhabitants should be lower than in the control samples due to the utilization of antioxidants that could scavenge the higher free radical concentrations. As shown in Attar et al. study, the total serum antioxidant level in Ramsar inhabitants was significantly lower than in the control samples [42]. Further evaluation on the antioxidant level of Takandeang Sub-village should be performed in future investigations to evaluate the association with individual radiosensitivity status.

\section{CONCLUSION}

Our study results showed that people living in Takandeang Sub-village inhabitants possibly developed the RAR phenomena. In this study, we 
did not find a significant association between radiosensitivity with the blood group and TP53 Arg72Pro polymorphism. We also noticed several limitations in our study. First, we only used a limited number of samples in this study. Second, we did not measure the annual effective dose and radon concentration in each house of our samples, particularly the Takandeang Sub-village inhabitants. There is a possibility that the levels of external and internal radiation exposures received by our samples varied from one to another. As a consequence, some individuals in Takandeang Sub-village inhabitants probably received lower external and internal radiation exposures than the others. A more comprehensive study using a larger number of samples in the future should be conducted to find the association between individual radiosensitivity with blood group types and TP53 Arg72Pro polymorphism.

\section{ACKNOWLEDGMENT}

The authors gratefully acknowledge the SAINTEK scholarship program of the Ministry of Research, Technology and Higher Education of the Republic Indonesia. This study was supported by grants from the National Nuclear Energy Agency of Indonesia (Badan Tenaga Nuklir Nasional) with contract number 080.01.06 3447.001 001.052.A and conducted as a BATAN Annual Research Project in 2016.

\section{REFERENCES}

1. S.M.J. Mortazavi and H. Mozdarani, Iran. J. Radiat. Res. 10 (2012) 111.

2. C.V. Karuppasamy, E.N. Ramachandran, V.A. Kumar et al., Mutat. Res. - Genet. Toxicol. Environ. Mutagen. 800 (2016) 40.

3. I.K.H. Basri, D. Yusuf, T. Rahardjo et al., J. Environ. Radioact. 171 (2017) 212.

4. H. Syaeful, I.G. Sukadana and A. Sumaryanto, Atom Indonesia 40 (2014) 33.

5. S. Nurhayati, S. Purnami and M. Syaifudin, Cytogenetic Evaluation in Peripheral Blood Lymphocytes of Individuals Living in High Natural Background Radiation of Botteng Village, Maтuju, Proceedings of the International Conferences on the Sources, Effects and Risks of Ionizing Radiation 2 (SERIR 2) (2016) 80.

6. T. Rahardjo, W. Mailana, T. Kisnanto et al., Int. J. Low Radiat. 10 (2017) 314.
7. S. Purnami and D. Ramadhani, Determination of Individual Radiosensitivity in Lymphocytes of Botteng Inhabitants Using Single Color FISH, Proceedings of the International Conferences on the Sources, Effects and Risks of Ionizing Radiation 2 (SERIR 2) (2016) 175.

8. S. Schmitz, K. Brzozowska, M. Pinkawa et al., Radiat. Res. 180 (2013) 465.

9. K. Claes, J. Depuydt, A.M.R. Taylor et al., NeuroMolecular Med. 15 (2013) 447.

10. F. Elahimanesh, A.S. Monfared, M. Khosravifarsani et al., Int. J. Mol. Cell. Med. 2 (2013) 131.

11. G. Alsbeih, R.S. Al-Meer, N. Al-Harbi et al., Radiother. Oncol. 119 (2016) 236.

12. Y. Li, N.-N. Feng, G.-H. Zhang et al., Int. J. Occup. Med. Environ. Health 26 (2013) 825.

13. S. Bayram, E. Rencüzoğulları, A.M. Almas et al., Toxicol. 39 (2016) 331.

14. J.H. Park, J. Zhuang, J. Li et al., FEBS Lett. 590 (2016) 924.

15. B.C. Melnik, Nutr. Metab. 14 (2017) 55.

16. M. Irshad, R.K. Mandal, A. Al-Drees et al., Asian Pacific J. Cancer Prev. 16 (2015) 5663.

17. K. Proestling, A. Hebar, N. Pruckner et al., PLoS One 7 (2012) 1.

18. I. Brasil-costa, D.O. Alencar, M. Raiol-moraes et al., BioMed Research International 2013 (2013) 1.

19. M. Syaifudin, S. Purnami, T. Rahardjo et al., J. Radiat. Environ. Med. 7 (2018) 65.

20. Anonymous, Sources and Effects of Ionizing Radiation, Annex A: Dose Assessment Methodologies, in: UNSCEAR 2000 Report to the General Assembly, with Scientific Annexes Vol. 1 Sources, United Nations, New York (2000) 19.

21. Anonymous, Sources and Effects of Ionizing Radiation: Sources Annex B. Exposures of the Public and Workers from Various Sources of Radiation, in: UNSCEAR 2000 Report to the General Assembly, with Scientific Annexes Vol. 1 Sources, United Nations, New York (2000) 83.

22. A. Baert, J. Depuydt, T. Van Maerken et al., Oncol. Rep. 37 (2017) 1379.

23. Anonymous, Cytogenetic Dosimetry: Applications in Preparedness for and Response to Radiation Emergencies, International Atomic Energy Agency, Austria (2011). 
24. A. Baert, J. Depuydt, T. Van Maerken et al., Breast Cancer Res. 18 (2016) 52.

25. X. Solé, E. Guinó, J. Valls et al., Bioinformatics 22 (2006) 1928.

26. N. Foray, C. Colin and M. Bourguignon, Radiology 264 (2012) 627.

27. S. Mohammadi, M. Taghavi-dehaghani, M.R. Gharaati et al., J. Radiat. Res. 47 (2006) 279.

28. J.R. Masoomi, S. Mohammadi, M. Amini et al., J. Environ. Radioact. 86 (2006) 176.

29. F.Z. Francies, O. Herd, X. Muller et al., South African Med. J. 105 (2015) 675.

30. O. Herd, F. Francies, J. Kotzen et al., Mol. Med. Rep. 13 (2016) 130.

31. M. Khosravifarsani, A.S. Monfared and S. Borzoueisileh, Electron. Physician 8 (2016) 2828.

32. M. Khosravifarsani, A.S. Monfared, H. Akhavan-Niaki et al., BMC Med. Phys. 12 (2012) 1 .
33. D. Saini, S. Shelke, A. Mani Vannan et al., Mol. Cell. Biochem. 364 (2012) 271.

34. G. Alsbeih, M. El-Sebaie, N. Al-Harbi et al., Int. J. Radiat. Oncol. Biol. Phys. 68 (2007) 229.

35. G. Alsbeih, N. Al-Harbi, M. Al-Buhairi et al., Radiat. Res. 167 (2007) 535.

36. J.L. Schwartz, D. Plotnik, J. Slovic et al., Environ. Mol. Mutagen. 52 (2011) 77.

37. L. Pereira, M.R.S. Carvalho, C.G. Fonseca et al., Genet. Mol. Res. 10 (2011) 3552.

38. S.M. Toprani and B. Das, Mutagenesis 30 (2015) 247.

39. S.M. Toprani and B. Das, Mutagenesis 30 (2015) 663.

40. Y. Kaneyuki, H. Yoshino and I. Kashiwakura, J. Radiat. Res. 53 (2012) 145.

41. M. Nenoi, B. Wang and G. Vares, Hum. Exp. Toxicol. 34 (2015) 272.

42. M. Attar, Y.M. Kondolousy and N. Khansari, Iran J. Allergy Asthma Immunol 6 (2007) 73. 